\title{
A Stepwise Regression Analysis of the Risk of Corporate Debt Default
}

\author{
Wang Zeyang ${ }^{1, a}$ \\ ${ }^{1}$ School of Banking \& Finance, University of International Business and Economics, Beijing, China \\ ${ }^{a}$ Email:duoerxs@163.com
}

\begin{abstract}
Nearly three years, the number of defaulting corporate on the Chinese bond market has risen sharply, and some bonds issued by state-controlled companies that are generally considered to be creditworthy have also defaulted, which all shows that the domestic bond market is changing. This paper selects possible influencing factors of 15 companies that have defaulted on debts in 2019 and 2020 from three aspects: internal objective factors, internal subjective factors, and external factors, using stepwise regression to conduct an empirical analysis on data. The results show that the nature of property rights positively and business illegality negatively correlate with corporate bond risk, which can be used as early warning indicators for corporate debt default risks. Combining with the conditions of the Chinese market, suggestions for the government and investors to reduce the risk of a corporate debt default are made, conducive to the stable operation of the domestic economy and the sustainable development of the bond market.
\end{abstract}

Keywords : Corporate debt, Default risk, Credit spread, Step regression.

\section{INTRODUCTION}

In recent years, due to the external factors that the popular influence the national economy and the managers' blind confidence, which lead to the internal factors of making the excessively radical development strategy, some enterprises' debt default has appeared in our country. From 2018 to 2020, the number and amount of debt default continuously rise and reach a shocking peak. Among them, the total of companies defaulting for the first time is as high as 21 , containing a large number of reputable state-owned enterprises. If the government and companies can not solve the dilemma in time, pessimistic expectations would be formed in financial market, causing that commercial banks and other main investors urgently retrieve funds, leading to a series of defaults, which is likely to give rise to debt crisis, induce regional risks, and even threaten the stable operation of the financial system. Finding the influencing factors and controlling the default risks within a reasonable range seems vital to avoid harmful consequences.

The prediction model of corporate debt default risk belongs to the category of the corporate financial distress prediction model. In the past decades, there were three main methods to measure the financial risk of companies. The first research in this field was Fitz Patrick(1932), who made a comparison of ratios between successful industrial enterprises and failed ones and emphasized the importance of Return On Equity(ROE) and Equity to Debt, two deciding ratios. Based on previous studies, Beaver(1966) added Cash-flow to Total-debt as one of alternative predictors, examined 79 failed firms, and discovered the best discriminating variable, Cash-flow to Total-debt and Net-income to Total-assets respectively. Instead of traditional ratio analysis, Altman(1968) introduced multiple discriminant analysis(MDA) and designed Z-score model, consisting of Working-capital to Total-assets, Retained-earnings to Total-assets, Marketvalue-equity to Book-value-of-total-debt, Earningsbefore-interest-and-taxes to Total assets and Sales to Total-assets, to predict the risks of financial obligations ${ }^{[1]}$. $\mathrm{Z}$-score model was a more accurate forecaster of failure up to years prior to bankruptcy than univariate analysis, but the accuracy diminished as the lead time increased. Altman(1977) established an upgraded version of the Zscore model, known as Zeta model, which added seven variables: Return on assets, Stability of earnings, Debt service, Cumulative profitability, Liquidity, Capitalization, and Size. Ohlson(1980) designed a conditional logistic model to measure the probabilistic prediction of bankruptcy by Size, Total liabilities divided by total assets, Performance measure, and Current liquidity. Bell(1990) published papers that compared the ability of the neural networks approach with the logistic 
model to predict commercial bank failures, followed by Coats and Fant(1992), who used the neural networks approach to forecasting financial distress. Many other scholars made improvements on the original basis of the model to be suitable for various economic situations without the emergence of revolutionary approaches ${ }^{[2]}$.

All three methods focus on objective factors within the companies, but ignore the subjective elements, for instance, the management ability and personalities of entrepreneurs, and external effect of financial market and policies. Therefore, in this paper, both subjective and objective factors are considered, as long as contributing to corporate bond defaults ${ }^{[3]}$.

This paper is organized into three sections. The first section briefly proposes possible factors that affect the default risk of corporate bonds, referring to the general default rate calculation methodology put by expertise scholars and rating agencies. We then review the analytic method of stepwise regression. At the same time, this paper selects 15 companies that have defaulted on corporate bonds in 2020 and 2019, constructs a predictive model of corporate bond default risk probability, and conducts an empirical analysis of the main influencing factors $^{[4]}$. Section 3 discusses the changing trend of debt risk in China and relative enlightenment.

\section{SELECTION OFSAMPLES AND VARIABLES}

\subsection{Selection of samples}

In this study, the subjects are large companies that issue bonds in the Chinese market, including listed companies and unlisted companies in the coal mining and washing industry, electronic equipment manufacturing industry, aerospace transportation industry, pharmaceutical industry, agricultural and sideline food processing industry, etc. There are each 15 defaulted companies in 2019 and 2020, having various size, which are extremely representative ${ }^{[5]}$. The major of these companies default on their debts for the first time, causing investors to lose confidence in purchasing additional corporate bonds and serious company financial crisis.

\subsection{Selection of indicators}

To propose a reasonable model of evaluating corporate bond default risks, we are requested to choose factors that can show the current state of operation and the possibility of debt refunding of companies comprehensively and typically. Availability of data should also be considered, which means indicators selected must have corresponding financial data and public information, ensuring the accuracy of empirical analysis results. Referring to indicators in the Zeta model and other relative models, we select 20 indicators in seven dimensions, including basic information, profitability, solvency, development ability, capital structure, market and entrepreneur confidence, which are introduced specifically in the table below. Among them, macro market information is an external factor that affects corporate debt default, entrepreneur information is an internal subjective factor, and the others are external subjective factors. Table 2 lists the descriptive statistical results of the variables, using statistics such as mean, standard deviation, median, maximum, minimum, and quartile to describe the scale and difference of 30 enterprise data.

The enterprise-related data comes from the wind database, and China's macro-market statistics come from the National Bureau of Statistics.

Table 1: Indicators for early warning of debt default risk

\begin{tabular}{|c|c|c|c|c|}
\hline \multicolumn{2}{|c|}{ Type } & Indicator & Name & Definition \\
\hline \multicolumn{2}{|c|}{ Explained variable } & Y & Credit spread & $\begin{array}{l}\text { The difference between the coupon rate at the time of corporate bond } \\
\text { issuance and the yield of treasury bonds of the same maturity in the same } \\
\text { period. }\end{array}$ \\
\hline \multirow{5}{*}{$\begin{array}{l}\text { Explanatory } \\
\text { variables }\end{array}$} & \multirow{5}{*}{$\begin{array}{c}\text { Basic } \\
\text { information }\end{array}$} & $\mathrm{X} 1$ & $\begin{array}{l}\text { Nature of } \\
\text { property } \\
\text { rights }\end{array}$ & $\begin{array}{c}\text { Central enterprises, local state-owned enterprises, foreign-funded } \\
\text { enterprises, public enterprises, and private enterprises are assigned value } \\
\text { to four to one, respectively. }\end{array}$ \\
\hline & & $\mathrm{X} 2$ & $\begin{array}{l}\text { Registered } \\
\text { capital }\end{array}$ & \\
\hline & & $\mathrm{X} 3$ & Credit rating & $\begin{array}{c}\text { AAA, AA, A, BBB, BB, B, CCC, CC, C are assigned nine to one points } \\
\text { respectively, and "+" represents } 0.25 \text { on the original basis, "-" represents } \\
\text { minus } 0.25 \text { on the original basis, according to the bond credit rating of } \\
\text { bond issuance by institutions. }\end{array}$ \\
\hline & & $\mathrm{X} 4$ & $\begin{array}{l}\text { Business } \\
\text { legitimacy }\end{array}$ & $\begin{array}{l}\text { The sum of the information on the person subject to enforcement, the } \\
\text { untrustworthy person, the judgment document, and the legal notice } \\
\text { received by the company in the year when the debt default occurred, then } \\
\text { divided into seven levels. From } 0 \text { to } 50 \text {, the first level is assigned seven } \\
\text { points, and one point is reduced for every } 50 \text { increase. }\end{array}$ \\
\hline & & $\mathrm{X} 5$ & $\begin{array}{c}\text { Guarantee } \\
\text { status }\end{array}$ & \\
\hline
\end{tabular}




\begin{tabular}{|c|c|c|c|c|}
\hline & \multirow{3}{*}{ Profitability } & $\mathrm{X} 6$ & ROE & Net profit/net assets \\
\hline & & $\mathrm{X} 7$ & ROA & Net profit/total assets \\
\hline & & $\mathrm{X} 8$ & $\begin{array}{l}\text { Gross profit } \\
\text { margin }\end{array}$ & Gross profit/operating income \\
\hline & \multirow{2}{*}{ Solvency } & X9 & Current ratio & Current assets/current liabilities \\
\hline & & $\mathrm{X} 10$ & Quick ratio & (Current assets-inventory) / current liabilities \\
\hline & \multirow{3}{*}{$\begin{array}{l}\text { Development } \\
\text { ability }\end{array}$} & $\mathrm{X} 11$ & $\begin{array}{l}\text { Net profit } \\
\text { growth rate }\end{array}$ & Net assets this year/absolute value of net assets last year \\
\hline & & $\mathrm{X} 12$ & $\begin{array}{l}\text { Growth rate of } \\
\text { total assets }\end{array}$ & Total assets this year/absolute value of total assets last year \\
\hline & & $\mathrm{X} 13$ & $\begin{array}{l}\text { Main business } \\
\text { income } \\
\text { growth rate }\end{array}$ & $\begin{array}{l}\text { Increase in main business income this year/absolute value of total main } \\
\text { business income last year }\end{array}$ \\
\hline & \multirow{2}{*}{$\begin{array}{l}\text { Capital } \\
\text { Structure }\end{array}$} & $\mathrm{X} 14$ & $\begin{array}{l}\text { Assets to } \\
\text { liabilities }\end{array}$ & Total liabilities/total assets \\
\hline & & $\mathrm{X} 15$ & Asset liquidity & Current assets/total assets \\
\hline \multicolumn{5}{|c|}{ (can be omitted) } \\
\hline Type & Indicator & Name & Definition & Definition \\
\hline \multirow{5}{*}{$\begin{array}{c}\text { Explanatory } \\
\text { variables }\end{array}$} & $\begin{array}{l}\text { Capital } \\
\text { Structure }\end{array}$ & $\mathrm{X} 16$ & $\begin{array}{c}\text { Current debt } \\
\text { ratio }\end{array}$ & Current liabilities/total liabilities \\
\hline & \multirow{3}{*}{ Market } & $\mathrm{X} 17$ & $\begin{array}{l}\text { Money } \\
\text { supply } \\
\text { quantity (M2) }\end{array}$ & \\
\hline & & $\mathrm{X} 18$ & $\begin{array}{c}\text { Deposit } \\
\text { reserve ratio } \\
\text { (large } \\
\text { financial } \\
\text { institutions) }\end{array}$ & \\
\hline & & X19 & Tax status & Income tax/operating income \\
\hline & $\begin{array}{l}\text { Entrepreneur } \\
\text { confidence }\end{array}$ & X20 & $\begin{array}{l}\text { Entrepreneur } \\
\text { confidence }\end{array}$ & $\begin{array}{l}\text { The index is compiled on the basis of judgment and expectation of } \\
\text { entrepreneurs on the overall production and operation of the } \\
\text { enterprises, comprehensively reflecting entrepreneurs' views and } \\
\text { confidence in the macro economy. }\end{array}$ \\
\hline
\end{tabular}

Table 2: Description of the variables

\begin{tabular}{ccccccccc}
\hline Variable & Obs & Mean & SD & Median & Max & Min & P25 & P75 \\
\hline $\begin{array}{c}\text { Credit spread } \\
\begin{array}{c}\text { Nature of property } \\
\text { rights }\end{array}\end{array}$ & 30 & $4.88 \%$ & $1.95 \%$ & $4.99 \%$ & $8.50 \%$ & $-3.05 \%$ & $4.15 \%$ & $5.94 \%$ \\
$\begin{array}{c}\text { Registered capital } \\
\text { Credit rating }\end{array}$ & 30 & 401298.74 & 1080291.73 & 0.00 & 6000000.00 & 10238.61 & 66982.52 & 287222.50 \\
Business legitimacy & 30 & 5.53 & 1.55 & 6.00 & 7.00 & 1.00 & 5.00 & 7.00 \\
Guarantee status & 30 & 807932.49 & 1574058.11 & 241725.95 & 7574668.00 & 0.00 & 59057.75 & 782954.21
\end{tabular}




\begin{tabular}{|c|c|c|c|c|c|c|c|c|}
\hline ROE & 30 & $-34.66 \%$ & $132.71 \%$ & $-0.16 \%$ & $160.52 \%$ & $-520.45 \%$ & $-24.76 \%$ & $2.12 \%$ \\
\hline ROA & 30 & $-21.76 \%$ & $42.67 \%$ & $-3.07 \%$ & $3.26 \%$ & $-207.09 \%$ & $-32.36 \%$ & $0.04 \%$ \\
\hline Gross profit margin & 30 & $10.76 \%$ & $37.14 \%$ & $17.50 \%$ & $57.25 \%$ & $-112.01 \%$ & $9.47 \%$ & $28.77 \%$ \\
\hline Current ratio & 30 & $99.23 \%$ & $66.02 \%$ & $90.00 \%$ & $309.00 \%$ & $20.00 \%$ & $59.25 \%$ & $110.00 \%$ \\
\hline Quick ratio & 30 & $68.57 \%$ & $58.11 \%$ & $63.00 \%$ & $261.00 \%$ & $5.00 \%$ & $33.00 \%$ & $84.75 \%$ \\
\hline Net profit growth rate & 30 & $-135.29 \%$ & $330.26 \%$ & $-9.70 \%$ & $102.19 \%$ & $-1195.81 \%$ & $-167.54 \%$ & $70.11 \%$ \\
\hline $\begin{array}{c}\text { Growth rate of total } \\
\text { assets }\end{array}$ & 30 & $-14.23 \%$ & $24.12 \%$ & $-4.28 \%$ & $10.29 \%$ & $-90.96 \%$ & $-15.46 \%$ & $-0.51 \%$ \\
\hline $\begin{array}{l}\text { Main business income } \\
\text { growth rate }\end{array}$ & 30 & $-134.08 \%$ & $326.92 \%$ & $-30.54 \%$ & $107.89 \%$ & $-1253.15 \%$ & $-170.99 \%$ & $69.22 \%$ \\
\hline \multicolumn{9}{|c|}{$\begin{array}{l}\text { (can be omitted) } \\
\text { (continued) }\end{array}$} \\
\hline Variable & Obs & Mean & SD & Median & Max & Min & $\mathrm{P} 25$ & P75 \\
\hline Assets to liabilities & 30 & $95.95 \%$ & $50.19 \%$ & $80.68 \%$ & $229.10 \%$ & $32.38 \%$ & $71.17 \%$ & $89.49 \%$ \\
\hline Asset liquidity & 30 & $49.88 \%$ & $20.64 \%$ & $50.78 \%$ & $88.61 \%$ & $9.01 \%$ & $40.67 \%$ & $60.68 \%$ \\
\hline Current debt ratio & 30 & $68.44 \%$ & $16.78 \%$ & $67.68 \%$ & $96.42 \%$ & $26.39 \%$ & $58.14 \%$ & $82.04 \%$ \\
\hline Money supply quantity & \multicolumn{3}{|c|}{$30 \quad 2099744.00 \quad 115192.14$} & \multicolumn{3}{|c|}{2099744.002213000 .001986488 .00} & 1986488.00 & 2213000.00 \\
\hline Deposit reserve ratio & 30 & $12.75 \%$ & $0.25 \%$ & $12.75 \%$ & $13.00 \%$ & $12.50 \%$ & $12.50 \%$ & $13.00 \%$ \\
\hline Tax status & 30 & $370.61 \%$ & $865.13 \%$ & $31.17 \%$ & $3457.50 \%$ & $0.11 \%$ & $8.46 \%$ & $100.78 \%$ \\
\hline $\begin{array}{l}\text { Entrepreneur } \\
\text { confidence }\end{array}$ & 30 & 123.52 & 0.08 & 123.52 & 123.60 & 123.44 & 123.44 & 123.60 \\
\hline
\end{tabular}

\section{ANALYSIS OF EVIDENCE}

\subsection{Stepwise regression model}

Stepwise regression analysis is a multiple regression analysis method, mainly applied to study the relationship between a dependent variable and other independent variables. It is widely used in the field of economics to explain the laws of economic operation, solve economic problems, and provide a basis for formulating policies ${ }^{[6]}$.

Stepwise regression combines the forward introduction and backward elimination methods, absorbing the advantages of the two methods. Its basic idea is that when the selected variable becomes unimportant after introducing a new variable, it can be eliminated, and the eliminated variable can be re-selected into the equation when it becomes important after the introduction of the new variable. Through this method that tests by many inspections, the regression equation obtained retains only a small number of variables with the most significant impact, showing the connection between them effectively and precisely.

Furthermore, there are often interrelationships between economic variables, which may cause multicollinearity of variables. The stepwise regression method employs the partial regression sum of squares to test the significance of variables so as to consider introducing or removing the variables, and the partial regression sum of squares test can generally be unified with the multicollinearity test between variables. Therefore, stepwise regression is able to correct multicollinearity to a certain extent ${ }^{[7]}$.

\subsection{Results of stepwise regression}

After normalizing the data, using the stepwise regression method to analysis, we can obtain results in table 3 .

The $\mathrm{R}$ value is 0.393 , which indicates $X 1$ and $X 4$ can explain the $39.3 \%$ change of $Y$, and the model passed the $\mathrm{F}$ test $(\mathrm{F}=8.744, \mathrm{p}=0.001<0.05)$, showing that the model is effective.

A test for the multicollinearity of the model finds that the model's VIF values are all smaller than 5, which means there is no collinearity problem, as well as the D$\mathrm{W}$ value is near 2, so that the model never have autocorrelation. There is no correlation between data, so the model works well. 
Table 3: Stepwise regression results

\begin{tabular}{|c|c|c|c|}
\hline & Regression coefficients & $95 \% \mathrm{CI}$ & VIF \\
\hline Constant & $0.484 * *(6.128)$ & $0.329 \sim 0.638$ & - \\
\hline Nature of property rights & $-0.195 * *(-2.777)$ & $-0.332 \sim-0.057$ & 1.006 \\
\hline Business legitimacy & $0.328 * *(3.333)$ & $0.135 \sim 0.521$ & 1.006 \\
\hline Sample size & & 30 & \\
\hline $\mathrm{R}^{2}$ & & 0.393 & \\
\hline Adjustment $\mathrm{R}^{2}$ & & 0.348 & \\
\hline F value & & $F(2,27)=8.744, p=0.001$ & \\
\hline
\end{tabular}

Dependent variable: Credit spread

$\mathrm{D}-\mathrm{W}$ value: 1.732

$* \mathrm{p}<0.05 * * \mathrm{p}<0.01$ The brackets indicate the $\mathrm{t}$ value

The stepwise regression model is

$$
Y=0.484-0.195 * X 1+0.328 * X 4
$$

The results emphasize $X 4$ have a significant positive influence on $\mathrm{Y}$, and $X 1$ has a significant negative influence on $\mathrm{Y}$, reflecting that state-owned enterprises have a lower probability of defaulting on debts than other enterprises. Besides, corporate with more illegal incidents have a higher probability of defaulting on debts.

\section{ANALYSIS}

In order to reduce the risk of corporate debt default, we make suggestions on two factors influencing credit spread, the nature of property rights and business legitimacy, for investors and government.

\subsection{Advice for nature of property rights}

State-owned enterprises, specifically central and local state-owned enterprises, always undertake social and strategic functions, mainly engaged in energy, transportation, infrastructure construction and other industries. To maintain the stability of the domestic economic market, the state provides invisible guarantees and support for state-owned enterprises, greatly reducing the financing costs of state-owned enterprises. In addition, when state-owned enterprises defaulted on bonds, the state often came forward to reorganize and merge enterprises to help them get out of trouble and regain a new life. Because of the above two reasons, investors optimistically estimate the risk-bearing level of stateowned enterprises ${ }^{[8]}$. They are willing to invest in bonds issued by state-owned enterprises, which makes stateowned enterprises have lower credit spreads, as the empirical results show. However, a large number of state- owned enterprises' defaults in the past two years indicate that the government is gradually delegating powers, giving play to the role of market regulation and reducing macro-control. Under these circumstances, investors should change traditional investment ideas, integrate financial data, guarantees, and macro-market operating conditions to objectively estimate the default risk of stateowned enterprises, rather than overestimate the riskbearing of state-owned enterprises ${ }^{[9]}$.

Compared with state-owned enterprises, foreignfunded enterprises and private enterprises are faced with higher financing costs and credit surplus, which hinders the development and expansion of the company. For the sustainable development of the national economy, in addition to continuing to promote marketization and reducing support policies and implicit guarantees for state-owned enterprises, the government should provide preferential financing policies and lower borrowing rates for foreign-funded enterprises and private enterprises so that state-owned enterprises can compete with other enterprises in the market fairly step by step.

\subsection{Advice for business legitimacy}

Although the legality of business operations is not easy to be noticed by investors, it actually has a serious impact on corporate reputation. The increasing number of enforced persons, dishonest persons, and judgment documents can be regarded as a signal of a decline in corporate reputation and inability to repay debt ${ }^{[10]}$.

In order to avoid the risk of bond defaults caused by business violations, the government is better to speed up the improvement of laws and regulations supervising the bond market and increase grassroots implementation and enforcement. Besides, commercial banks or institutional 
investors could provide short-term loans within one year for first-time default companies with good credit, therefore, profitable companies have the capability of continuing to operate for profits and repay debts.

\section{CONCLUSION}

Based on empirical analysis results, the corporate bond default risk is related to indicators that affect corporate credit, rather than the company's financial data in the past. While paying attention to financial indicators, enterprises should emphasize maintain a good level of credit in terms of operating legitimacy and external guarantees. At the same time, investors should also focus on the company's credit rating and use multiple indicators to objectively evaluate the risk of corporate default and reduce investment losses. The government should streamline administration and delegate powers, transform its functions from participants in the securities market into supervisors. Giving full play to the market regulation mechanism to survive the fittest is conducive to improving enterprise product service quality and management capabilities and promoting economic development.

\section{REFERENCES}

[1] Fitzpatrick, F. (1932) A Comparison of Ratios of Successful Industrial Enterprises with Those of Failed Firm. Certified Public Accountant, 6, 727731.

[2] Beaver, W. (1966). Financial Ratios As Predictors of Failure. Journal of Accounting Research, 4, 71-111. doi: $10.2307 / 2490171$

[3] Altman, E. (1968). Financial Ratios, Discriminant Analysis and the Prediction of Corporate Bankruptcy. The Journal of Finance, 23(4), 589-609. doi: $10.2307 / 2978933$

[4] Altman, E. I., Haldeman, R. G., \& Narayanan, P. (1977). ZETA Analysis: A New Model to Identify Bankruptcy Risk of Corporations. Journal of Banking and Finance, 1, 29-54. doi:10.1016/03784266(77)90017-6

[5] Ohlson, J. (1980). Financial Ratios and the Probabilistic Prediction of Bankruptcy. Journal of Accounting Research, 18(1), 109-131. doi: $10.2307 / 2490395$

[6] You Soldier \& Yan Yan. (2017). Stepwise regression analysis and its application. Statistics and Decision (14), 31-35. doi:10.13546/j.cnki.tjyjc.2017.14.007.

[7] Shi Yanping \& Liu Eping. (2019). The nature of property rights, risk taking and corporate bond credit spreads. East China Economic Management (01), 119-128. doi:10.19629/j.cnki.34-1014/f.171023016.
[8] Zhang Jun. (2021). Research on bond market reform and investor risk awareness-evidence from corporate bond issuance pricing. Securities Market Herald (01), 56-63. doi:CNKI:SUN:ZQDB.0.202101-006.

[9] Wang Li. (2008). Research on the financial early warning of my country's listed transportation companies based on the "Z-Score" model (Master's thesis, Civil Aviation University of China). https://kns.cnki.net/KCMS/detail/ detail.aspx dbname $=$ CMFD2009\&filename $=20081$ 59527.nh

[10] Liang Haina. (2019). Internal control quality and corporate bond credit spreads (Master's thesis, Beijing Jiaotong University). https://kns.cnki.net/KCMS/detail/detail.aspx?dbna $\mathrm{me}=\mathrm{CMFD} 202001 \&$ filename $=1019209398 . \mathrm{nh}$ 